\title{
Topeng Wayang Kerte Desa Kotakan Kabupaten Situbondo
}

\author{
Sigit Setiawan, Mei Artanto \\ Fakultas Ilmu Budaya, Universitas Jember \\ Sigitawan03@gmail.com
}

\begin{abstract}
Abstrak
Kegiatan ini merupakan bentuk pengabdian kepada masyarakat sebagai bagian dari pelaksanaan Tri Dharma Perguruan Tinggi. Adapun mitra yang dipilih dalam kegiatan ini adalah masyarakat Desa Kotakan, Kecamatan Situbondo, Kabupaten Situbondo, Jawa Timur. Mitra merupakan desa dengan potensi wisata seni yang mempunyai produk ikonik Topeng Wayang Kerte serta memilikii nilai tambah di mana letak daerahnya berada di dalam kota. Ironisnya, produk wisata tersebut belum menjadi produk unggulan mitra untuk meningkatkan kesejahteraan hidupnya. Permasalahan yang dihadapi mitra saat ini adalah mengenai; (l) produktivitas pembuatan Topeng Wayang Kerte yang mengalami kendala pada konsistensi proses produksi dan varian produk dan (2) manajemen pemasaran. Kendala produktivitas antara lain tercermin dalam proses produksi yang masih tergantung pada pesanan, tanpa adanya kesadaran untuk membuat produk yang siap jual dan varian topeng kerte yang hanya terpaku pada fungsinya sebagai properti pentas serta belum menyasar pada bentuk varian lainnya. Sementara pada manajemen pemasaran, mitra belum memaksimalkan media-media yang ada untuk menampung produk siap jual seperti galeri seni dan juga sosial media atau internet. Solusi yang ditawarkan kepada mitra atas kendala pertama adalah sosialisasi mengenai manajemen produksi sehingga dapat melakukan proses produksi secara berkesinambungan. Dari sana mitra tidak hanya melakukan produksi bila ada pesanan tetapi sudah siap produk bila sewaktuwaktu ada konsumen datang. Kemudian yang juga penting adalah mitra dapat mengembangkan dan membuat varian produk-produknya menjadi yang lebih kreatif. Terkait dengan manajemen pemasaran akan dibuatkan konsep tempat pameran/galeri Topeng Wayang Kerte dan memberikan sosialisasi untuk memaksimalkan sosial media dan internet sebagai sarana pemasaran. Mengingat Program Pariwisata bertajuk Tahun Kunjungan Wisata 2019 yang dicanangkan Pemkab Situbondo, pengabdian ini merupakan satu upaya untuk menggali local wisdom yang dimiliki Situbondo untuk nantinya dapat menjadi bagian dari program yang dimaksud.
\end{abstract}

Kata Kunci: Topeng, Kerte, Kothakan, Wisata

\section{Abstract}

This activity is a form of community service as part of the implementation of the Tri Dharma of Higher Education. The partners chosen in this activity were the community of Kotakan Village, Situbondo District, Situbondo Regency, East Java. Partners are villages with the potential of art tourism that have iconic products of Wayang Kerte Mask and have added value where the location of the area is in the city. Ironically, these tourism products have not become the partner's superior products to improve their welfare. The problems faced by partners today are about; (1) the productivity of making Wayang Kerte Mask which has problems in the consistency of the production process and product variants and (2) marketing management. Productivity constraints are reflected, among others, in the production process that is still dependent on orders, without the awareness of making products that are ready to sell and variants of the Kerte mask which are only fixed on their function as stage properties and have not targeted other variants. While in marketing management, partners have not maximized existing media to accommodate ready-to-sell products such as art galleries and also social media or the internet. The solution offered to partners for the first obstacle is socialization of production management so that it can carry out sustainable production processes. From there partners do not only produce if there is an order but are ready for the product if at any time a consumer comes. Then what is also important is that partners can develop and make 
variants of their products become more creative. Related to marketing management, the concept of the Wayang Kerte Mask exhibition / gallery place will be made and provide socialization to maximize social media and the internet as a marketing tool. Considering the Tourism Program titled the Year of Tourism Visit 2019 launched by the Situbondo Regency Government, this service is an effort to explore the local wisdom that Situbondo has to later become part of the program in question.

Keywords:Mask, Kerte, Kothakan, Tourism

\section{PEMBAHASAN}

Secara geografis Kabupaten Situbondo terletak di ujung Timur Pulau Jawa Bagian Utara antara $113^{\circ} 30^{\prime}-114^{\circ} 42^{\prime}$ Bujur Timur dan antara $7^{\circ} 35^{\prime}-7^{\circ} 44^{\prime}$ Lintang Selatan dengan temperatur tahunan $24,7^{\circ} \mathrm{C}-27,9^{\circ} \mathrm{C}$. Daerah fisiknya memanjang dari Barat ke Timur sepanjang Pantai Selat Madura $\pm 158 \mathrm{Km}$ dengan lebar rata-rata $\pm 11 \mathrm{Km}$. Batas Wilayah Kabupaten Situbondo sebelah barat Kabupaten Probolinggo, sebelah utara Selat Madura, sebelah timur Selat Bali, sebelah selatan Kabupaten Bondowoso dan Kabupaten Banyuwangi. Kabupaten Situbondo memiliki wilayah seluas $1.638,50 \mathrm{Km}^{2}$ dan secara administrasi terbagi menjadi 17 Kecamatan, 132 Desa, 4 Kelurahan, 660 Dusun/Lingkungan (situbondokab.go.id).

Sebagai daerah dengan sosial masyarakat Madura dan agama mayoritasnya adalah Islam, Situbondo mempunyai potensi wisata yang sangat banyak. Beberapa di antaranya adalah wisata alam, wisata sejarah dan wisata religi. Masing-masing obyek wisata tersebut terkonsentrasi pada masing-masing bidang seperti wisata religi yang terkosentrasi pada pondok-pondok pesantren besar maupun makam-makan ulama di Situbondo. Wisata alam seperti wilayah pantai, pegunungan dan Taman Nasional Baluran. Sedangkan wisata-wisata sejarah berkonsentrasi pada bangunan-bangunan bersejarah seperti Pabrik Gula dan Rumah Bupati Situbondo.

Selain potensi-potensi wisata di atas, terdapat satu ikon khas Situbondo yang berangkat dari wisata seni. Potensi ini ada karena Situbondo apabila dilihat dari peta persebaran kebudayaan (seni) masuk dalam lokus budaya Madura. Maka di Situbondo kesenian Madura tumbuh dan berkembang. Salah satu ikonik Situbondo adalah kesenian Wayang Topeng Kerte. Pertunjukan Wayang Kerte menggunakan topeng sebagai properti utama.

Topeng Kerte merupakan seni wayang orang yang berkembang di Situbondo pada tahun 1930-an (Bovier, 2002: 120). Nama pendirinya adalah Kertesuwignyo (Hidayah dan Tjintariani, 2015 : 106). Istilah Kerte merujuk pada seorang dalang wayang kulit, karena tidak begitu laku maka diganti menjadi wayang kulit ( Wawancara dengan Sukran dalam Hidayatullah, 2018: 41-42). Secara bentuk topeng-topeng yang hadir dalam pertunjukan Kerte juga sangat variatif. Hidayah dan Tjintariani membaginya menjadi 41 karakter, dengan 22-24 di antaranya sering digunakan dalam pertunjukannya. Lebih lanjut mereka membagi topeng Kerte menjadi beberapa kelompok, yaitu Topeng Alos, Topeng Kasaran, Topeng Ksatria, Topeng Potre, dan Punakawan (Hidayah dan Tjintariani, 2015 : 103-107).

Saat ini secara kwantitas pertunjukannya sangat berkurang. Hal ini berpengaruh terhadap produksi topeng Kerte di Kotakan, Situbondo. Topeng-topeng wayang Kerte tetapmasih diproduksi oleh para pengrajin topeng kerte meski dalam jumlah yang sangat terbatas, mengingat kini pertunjukan topeng Kerte sangat jarang bahkan nyaris punah. Topeng yang dalam hal ini dilihat sebagai sebuah kerajinan, dilihat sebagai potensi yang masih dapat dipertahankan dan dilestarikan. Selain hal tersebut, Topeng Kerte merupakan ciri khas dari Desa Kotakan. Bersamaan dengan pro- 
gram pariwisata Kabupaten Situbondo tahun 2019, maka kerajinan topeng Kerte menjadi sangat potensial sebagai salah satu produk potensi wisata di Kabupaten Situbondo, khusunya di Desa Kotakan.

Bersamaan dengan aspek pariwisata ini, Pemerintah Kabupaten Situbondo mempunyai program menyongsong Tahun Kunjungan Wisata 2019. Dalam program tersebut, Pemkab Situbondo menjadikan aspek wisata sebagai program utama di tahun 2019. Artinya Pemkab Situbondo harus memaksimalkan segala potensi wisata yang ada untuk kemudian digunakan sebagai komoditas dalam program tersebut.

Topeng Kerte merupakan salah satu produk lokal yang mempunyai potensi wisata dengan nilai jual tinggi apabila produksi dan pemasarannya dikelola dengan baik. Pengelolaan inilah yang akan disasar dalam program pengabdian ini yakni membantu masyarakat produsen topeng Kerte dapat meningkatkan produktivitasnya serta mempunyai manajemen pemasaran yang baik sehingga menjadi komoditas yang layak untuk dipamerkan dalam program Kunjungan Wisata Situbondo tahun 2019.

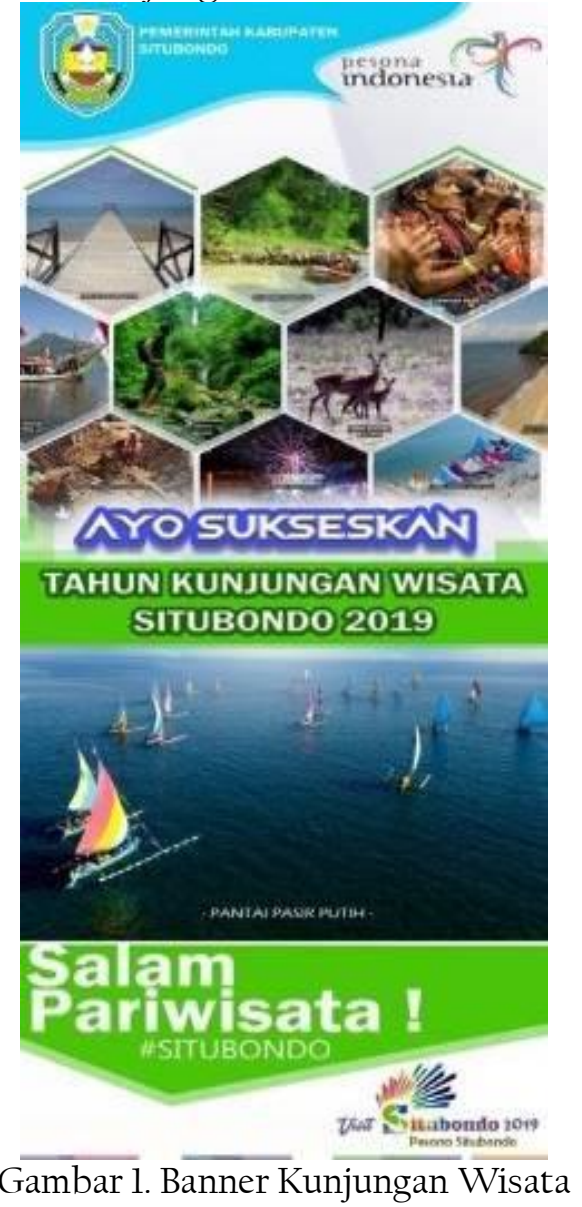

Situbondo 2019(Foto: situbondokab.go,id)

Masyarakat yang menjadi produsen Topeng Kerte adalah masyarakat Desa Kotakan, Kabupaten Situbondo. Desa Kotakan merupakan desa yang didesain sebagai desa wisata di mana Topeng Kerte merupakan produk unggulannya. Kemampuan (skill) masyarakat Desa Kotakan dalam membuat topeng Kerte dinilai baik dalam hal kualitas produknya. Keunikannya, apabila topeng didaerah-daerah lain menggunakan kayu sebagai bahan utama, masyarakat Desa Kotakan dapat membuatnya dari bahan kertas yang noatbene harga bahannya tentu lebih murah daripada kayu. Meskipun juga masyarakat Desa Kotakan juga dapat membuat topeng Kerte dari kayu. Poin utamanya, 
bahan kertas merupakan solusi atas mahalnya harga kayu, dan kertas merupakan bahan dapat dijumpai dan didapatkan dengan mudah - dibanding kayu.

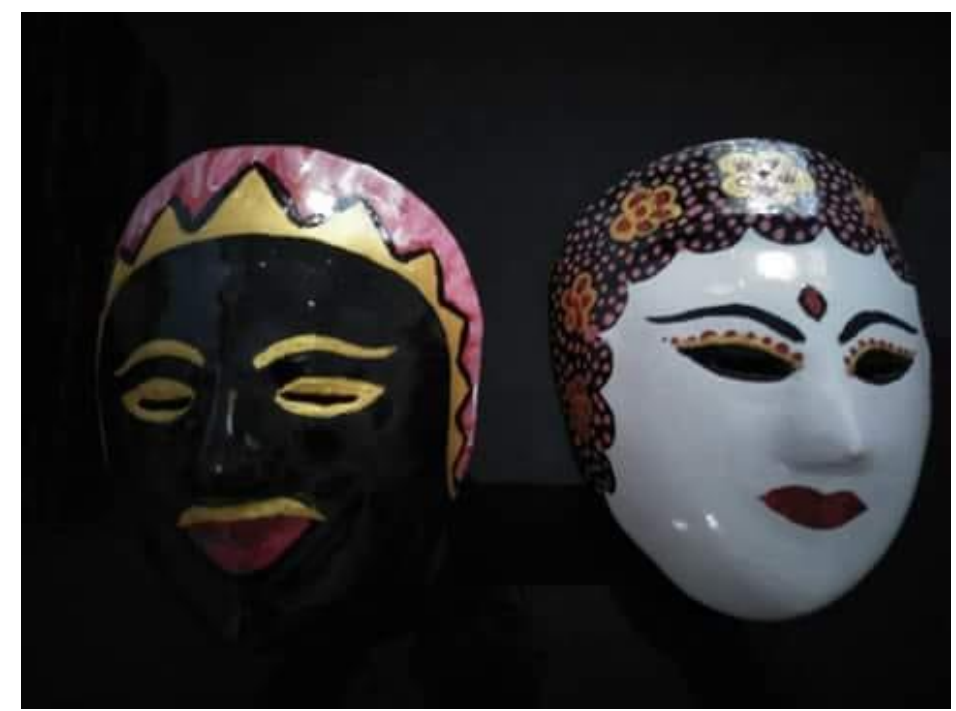

Gambar 2. Kerajinan Topeng Kerte (Foto: Mitra, 2019)

Secara geografi, Desa Kotakan terletak di tengah Kota (Kabupaten) Situbondo. Artinya Desa Kotakan mempunyai akses yang lebih mudah untuk dikunjungi oleh wisatawan yang ingin mendapatkan dan mengetahui proses pembuatan Topeng Wayang Kerte. Hal ini nantinya merupakan nilai tambah bagi masyarakat Desa Kotakan yang dekat dengan pusat administrasi dan transportasi. Dari pemaparan di atas jelas sudah peta wisata Desa Wisata sentra kerajinan Topeng Wayang Kerte Desa Kotakan Situbondo, yakni SDM (skill) yang dimiliki dan letak geografi yang mendukung.

\section{A. Permasalahan Mitra}

Berdasarkan analisis terhadap situasi keadaan lingkungan pada mitra, dapat disimpulkan bahwa masyarakat Desa Kotakan siap secara SDM, dalam artian keahlian membuat Topeng Kerte dan memiliki keuntungan secara geografi karena keberadaannya yang ada di tengah Kota Situbondo sehingga secara tidak langsung mempermudah akses menuju Desa Kotakan. Dari sana hal yang penting untuk dilakukan adalah membantu masyarakat Desa Kotakan sebagai sentra produksi Topeng Kerte dengan dua hal, yakni; pertama, membantu masyarakat Desa Kotakan dalam peningkatan produktivitas Topeng Wayang Kerte dan kedua, manajemen pemasaran Topeng Wayang Kerte.

Produksi perlu ditingkatkan mengingat selama ini masyarakat Desa Kotakan masih menggunakan sistem produksi tradisional. Dalam proses produksi Topeng Wayang Kerte masyarakat masih mengandalkan pesanan-pesanan yang datang dari konsumen. Dengan kata lain, bahwa produksi Topeng Wayang Kerte dilakukan bila ada pesanan dari konsumen. Apabila tidak ada pesanan maka proses produksi tidak akan ada. Hal ini mengindikasikan dua hal. Pertama; proses produksi tidak menyediakan produk yang siap jual bagi konsumen. Dengan tidak adanya stok produk tersebut konsumen tidak dapat melakukan survei karena tidak ada produk yang siap untuk dibeli. Kedua, transaksi pemesanan tersebut membuat konsumen harus menunggu hingga produk itu jadi. Artinya ada waktu tunggu bagi konsumen. Dengan kata lain, tidak semua konsumen mau untuk menunggu. Bagi konsumen baru mereka 
pasti menghendaki produk yang siap dibeli dan dibawa pulang saat itu juga. Artinya masyarakat Kotakan harus memiliki stok Topeng Wayang Kerte. Hal inilah yang selama ini tidak dilakukan oleh masyarakat Kotakan karena masih berkutat pada sistem tradisional "ada pesan ada barang" bukan "ada uang ada barang". Proses produksi seperti ini menjadi penghambat perkembangan proses produksi.

Setelah menyelesaikan masalah produktivitas, persoalan kedua yang dihadapi masyarakat Desa Kotakan adalah manajemen pemasaran. Manajemen pemasaran yang dimaksud meliputi gerai atau tempat menyimpan dan memamerkan produk-produk yang telah diproduksi dan media pemasarannya. Hingga saat ini selain belum adanya produksi Topeng Wayang Kerte yang berkesinambungan, di Desa Kotakan juga belum tersedia tempat penyimpanan atau tempat pameran sebagai wadah produk-produk mereka. Masalah terakhir yang dihadapi adalah manajemen pemasaran. Masyarakat Desa Kotakan selama ini masih menggunakan menajemen pemasaran tradisional, yakni mengandalkan tradisi oral, gethok tular antar warga dalam memasarkan produknya. Beberapa potensi seperti digitalisasi produk sehingga menjadikannya produk yang bisa dilihat secara on-line belum dilakukan. Penggunaan sosial media sebagai sarana pemasaran juga belum maksimal serta pengetahuan penggunaan sarana pemasaran melalui media internet belum banyak diketahui. Aspek-aspek inilah yang nanti akan dimaksimalkan dalam pengabdian ini sehingga mampu mendorong pemasaran Wayang Topeng Kerte lebih meningkat dan signifikan, yang tidak hanya di kancah lokal, tetapi nasional bahkan bukan tidak mungkin kedepannya merambah kepada pasar internasional.

\section{B. Tujuan Program}

Berdasarkan analisis terhadap permasalahan yang dihadapi oleh mitra, maka tujuan dari dilaksanakannya program pengabdian ini adalah :

1. Membantu mengatasi keterbatasan pengetahuan dan pemahaman mengenai maksimalisasi produk berupa Topeng Wayang Kerte.

2. Memberikan materi pelatihan manajemen pemasaran produk kepada masyarakat Desa Kotakan Situbondo dalam mengelola produk; Topeng Wayang Kerte melalui promosi dengan media, baik media offline maupun online berdasarkan teknologi yang berkembang.

3. Mendukung kegiatan pariwisata yang akan digelar oleh pemerintah Situbondo pada tahun 2019.

4. Membantu masyarakat Desa Kotakan dalam memunculkan ikon daerahnya.

\section{PEMBAHASAN}

Solusi atas permasalahan yang dihadapi mitra di atas ada dua. Pertama adalah memberikan metode pelatihan mengenai cara memaksimalkan produktivitas masyarakat Desa Kotakan dalam produksi Topeng Wayang Kerte. Kedua, adalah memberikan wawasan pemasaran atas produk-produk mereka.

Solusi pertama adalah memaksimalkan produktivitas Topeng Wayang Kerte di Desa Kotakan Situbondo. Masalah di atas diatasi dengan pemberian pelatihan produksi yang baik. Mengajarkan kepada mereka bagaimana kiat supaya proses produksi dapat dilakukan dengan terus berkesinambungan tanpa harus menanti pesanan. Pelatihan tersebut nantinya memberikan pengalaman riil mengenai proses produksi dengan hasil produk yang siap jual dan siap di tempat. Untuk mendongkrak produktivitas Topeng Wayang Kerte, maka masyarakat Desa Kotakan juga akan diarahkan untuk 
mengembangkan produk-produknya. Selama ini, masyarakat Desa Kotakan masih menjadikan Topeng Kerte yang diproduksi sebatas properti pentas dari pertunjukan Wayang Kerte tradisional dan juga melayani pesanan ketika ada acara festival kesenian di Situbondo. Dengan demikian proses produksi ini juga tergantung kepada jadwaljadwal pertunjukan seni secara umum, dan pertunjukan Wayang Kerte secara khusus. Di luar dua hal tersebut produksi Topeng Wayang Kerte tidak dapat dilakukan. Untuk alasan itulah masyarakat Desa Kotakan memerlukan produk-produk lain yang dapat dihadirkan selain topeng wayang kerte. Beberapa opsi luaran yang akan kami tawarkan adalah memproduksi Topeng Wayang Kerte dalam bentuk-bentuk baru seperti souvenir, gantungan kunci, hiasan dinding dan lain sebagainya. Hal ini sekaligus menambah warna baru produk Topeng Wayang Kerte.

Luaran di atas juga akan didukung dengan mengkonsep tempat - art gallery. Maka pengabdian ini memberikan solusi bagaimana membuat dan merawat galeri Topeng Wayang Kerte, berikut katalog-katalog mengenai Topeng Wayang Kerte. Galeri ini akan menjadi tempat kunjungan para wisatawan yang datang ke Desa Kotakan berikut mendapatkan (membeli) Topeng Wayang Kerte.

Dalam hal pemasaran solusi yang kami tawarkan dalam pengabdian ini adalah metode memaksimalkan media sosial dan internet sebagai wahana pemasaran baru. Luaran yang ditawarkan adalah membuatkan blog berisi produk-produk Topeng Wayang Kerte, media sosial facebook, membuat video dan diunggah di laman You Tube, dan mengunggahnya di laman internet pemerintah Kabupaten Situbondo (situbondokab.go.id).

\section{III.PEMBAHASAN}

Untuk menyelesaikan masalah yang dihadapi dan dalam pencapaian tujuan yang telah ditetapkan, maka dilakukan kegiatan-kegiatan dengan mengintegrasikan unsur-unsur pengetahuan manajeman seni pertunjukan yang baik begiu pula dengan pengetahuan metode pola promosi melalui media offline maupun secara online. Serangkaian kegiatan itu dilakukan sebagai usaha untuk meningkatkan produktivitas pementasan musik patrol dan antusias berkesenian bagi mitra yang akan melaksanakan program ini.

Secara rinci kegiatan-kegiatan yang dilakukan diuraikan sebagai berikut;

\section{A. Deskripsi Kegiatan}

Pihak mitra merupakan pembuat Topeng Wayang Kerte tradisional di Desa Kotakan, Situbondo, yang telah lama menggeluti bidangnya, akan tetapi minimnya pengetahuan dan pemahaman dalam memaksimalkan produktivitas dan manajemen pemasaran secara komprehensif dan hanya berbekal pengalaman yang didapat secara otodidak di lapangan, akhirnya proses produksi dan pemasaran berjalan dalam keadaan stagnan dan tidak optimal,sehingga berdampak pada kurangnya kreatifitas dalam pola produksi dan pemasaran produk Topeng Wayang Kerte. Berdasarkan analisis permasalahan yang telah diuraikan pada bab sebelumnya, maka tahapan -tahapan kegiatan yang akan dilaksanakan dalam program ini adalah sebagai berikut :

* Sosialisasi bentuk program dalam meningkatkan produktivitas Topeng Wayang Kerte.

* Pelatihan dan pembekalan pengetahuan mengenai manajemen pemasaran.

* Pelatihan pembuatan topeng dalam bentuk yang lebih variatif.

* Pendampingan proses pembuatan dan pola promosi produk dengan penggunaan media internet. 
* Evaluasi hasil kegiatan.

\section{B. Manajeman dan Pelatihan Kegiatan}

\section{Perancangan Kegiatan}

\section{a. Metode Pelaksanaan}

Kegiatan Pengabdian ini dirancang meliputi 2 kegiatan yaitu pertama mengadakan pelatihan produksi dan kedua, pembinaan mengenai manajemen pemasaran. Untuk kegiatan pertama dirancang dengan sistematis dengan mengundang pakar atau ahli dalam bidang produksi dan pakar atau ahli dalam bidang pembuatan karya seni rupa. Adapun output dari proses kegiatan ini adalah pemahaman dan keterampilan dalam menerapkan produksi produk-produk baru sesuai dengan selera masyarakat. Kedua adalah menggandeng ahli desain dan pengkarya audio visual untuk kemudian dapat mendongkrak pemasaran produk melalui media internet.

Mekanisme dan rancangan kegiatan pelatihan ini bagi dalam tiga tahapan yang meliputi tahap persiapan, pelaksanaan, dan pelaporan. Tahapan persiapan yang dilakukan dengan membentuk tim yang terdiri atas, ketua panitia, sekretaris, dan anggota. Tugas penanggung jawab adalah menjamin keberlangsungan seluruh rangkaian kegiatan, sedangkan ketua, sekretaris, dan anggota mempersiapkan sampai dengan melaksanakan kegiatan. Setelah tim terbentuk menyusun rancangan kegiatanselanjutnya menghubungi narasumber berdasarkan dengan kompetensi yang dimiliki dan disesuaikan dengan kebutuhan materi dari pelaksanaan pelatihan. Pemateri adalah profesional dan pakar yang dipandang betul-betul memiliki kompetensi terkait dengan bidang manajemen dan pembuatan karya seni rupa serta audio visual.

Adapun rancangan materi dari workshop meliputi:

\begin{tabular}{|c|c|c|c|}
\hline No. & Materi & Pemateri & Institusi \\
\hline 1. & $\begin{array}{l}\text { Materi pengantar tentang desain dan } \\
\text { manajemen pemasaran media } \\
\text { internet }\end{array}$ & $\begin{array}{l}\text { Harry Kresno Setiawan, } \\
\text { S. S., M. M. }\end{array}$ & $\begin{array}{l}\text { Fakultas } \\
\text { Ilmu Budaya } \\
\text { UNEJ }\end{array}$ \\
\hline 2. & $\begin{array}{l}\text { Pemaparan materi pembuatan blog, } \\
\text { web desain dan media sosial }\end{array}$ & Deni Antyo S. Sn. M. Sn. & $\begin{array}{l}\text { Fakultas } \\
\text { Ilmu Budaya } \\
\text { UNEJ }\end{array}$ \\
\hline
\end{tabular}

Setelah diperoleh narasumber, maka tim memasuki tahapan pelaksanaan. Sebelum tahapan pelaksanaan tim akan mempersiapkan seluruh sarana dan prasarana pendukung untuk memperlancar pelaksanaan kegiatan. Tahapan-tahapan yang dilaksanakan meliputi: pengadaan sarana akomodasi bagi pembicara. Kemudian memastikan tempat pelaksanaan dengan melakukan koordinasi dengan pihak-pihak yang terlibat, menyediakan sarana penunjang workshop seperti tool kits peserta sekaligus konsumsi. Kegiatan ini dilaksanakan selama satu hari.

Adapun kegiatan pelatihan akan diikuti oleh masyarakat Desa Kotakan, Kecamatan dan Kabupaten Situbondo. Setelah dilaksanakan seluruh rangkaian kegiatan pelatihan, maka ketua panitia menyusun pelaporan pelaksanaan kegiatan yang terdiri atas laporan narasi pelaksanaan dan laporan pertanggungjawaban keuangan yang diketahui oleh Penanggungjawab kegiatan. 


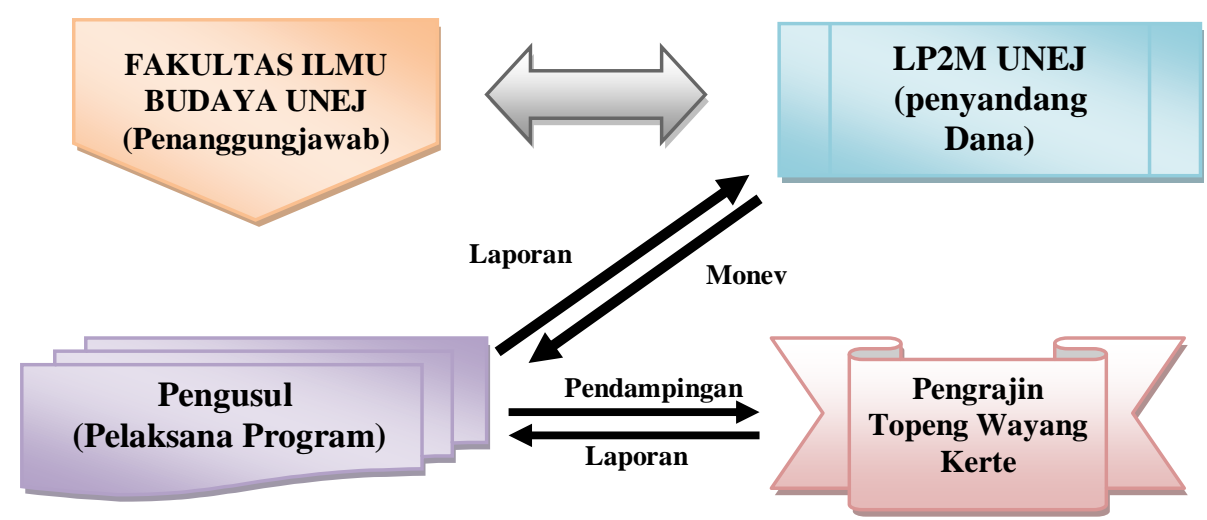

Gambar 3. Pola Kemitraan diantara kelompok-kelompok terkait

\section{IV.PENUTUP}

Dalam proses pengabdian kepada masyarakat Desa Kotakan Kabupaten Situbondo beberapa hasil yang telah tercapai adalah meliputi; 1) Observasi lapangan untuk menentukan dan pemetaan peta masyarakat yang mengikuti pelatihan, 2) Pelatihan berikut produk yang dihasilkan dari pengabdian; a. Produk Topeng Wayang, b. Variasi Produk Topeng Wayang, c. Pembuatan dan Pengelolaan Web, d. Video Company Profile, 3) Membantu Konsep Galeri Seni untuk Topeng Wayang Kerte, 4) Menentukan road map desa Kothakan sebagai destinasi Wisata Topeng Kerte Situbondo. Keempatnya dijabarkan sebagai berikut.

\section{A. Observasi}

Observasi dilakukan dalam dua kali sesi. Sesi pertama adalah kegiatan untuk mengetahui potensi wisata di Desa Kotakan. Bertemu dengan masyarakat Desa Kotakan kemudian memetakan kendala yang dihadapi oleh masyarakat Kotakan dalam hal produksi dan manajemen produk mereka. Dari pertemuan dengan masyarakat Kotakan, atas berbagai pertimbangan dengan Kepala Desa dan Sekretaris Desa maka dibentulah satu Kelompok Pelestari Topeng Kerte. Kelompok ini menamakan dirinya Komunitas "Kaliyuga" Pelestari Topeng Kerte Situbondo. Kelompok ini diketuai oleh Sekretaris Desa Kotakan. Sasarannya adalah ibu-ibu dan anak muda yang peduli dalam pelestarian Topeng Kerte. Mereka yang nantinya akan diberikan pelatihan mengenai produksi Topeng Kerte dan manajemen pemasarannya. Anggota kelompoknya terdiri dari 15 orang yang terbagi dalam 6 orang merupakan pembuat topeng Kerte pemula, 6 orang pembuat variasi produk Topeng Kerte, dan 3 orang dilatih dalam hal pemasaran secara daring produk-produk dari pengrajin Topeng Kerte.

\section{B. Pelatihan dan Produk}

Pelatihan dalam pengabdian ini dibagi menjadi tiga bagian. Pertama pelatihan bagi para pembuat topeng Wayang Kerte pemula, kedua pelatihan bagi para pembuat topeng kerte produksi wayang kerte yang sudah professional untuk kemudian membuat varian produk, dan ketiga adalah pelatihan manajemen pemasaran melalui daring. Berikut penjabarannya.

\section{Pelatihan Produksi Wayang Topeng Kerte}

Pelatihan ini dilakukan di Desa Kotakan dengan sasaran adalah 6 orang yang masih awam tentang proses pembuatan topeng wayang Kerte. Prosesnya diawali dari pencampuran bahan-bahan topeng kerte kemudian ditempatkan pada cetakan yang 
telah disediakan yang berupa karakter tokoh-tokoh wayang Kerte. Setelah proses cetakan selesai kemudian cetakan tersebut ditempel/ ditambal dengan kertas Koran, kemudian dijemur hingga kering.

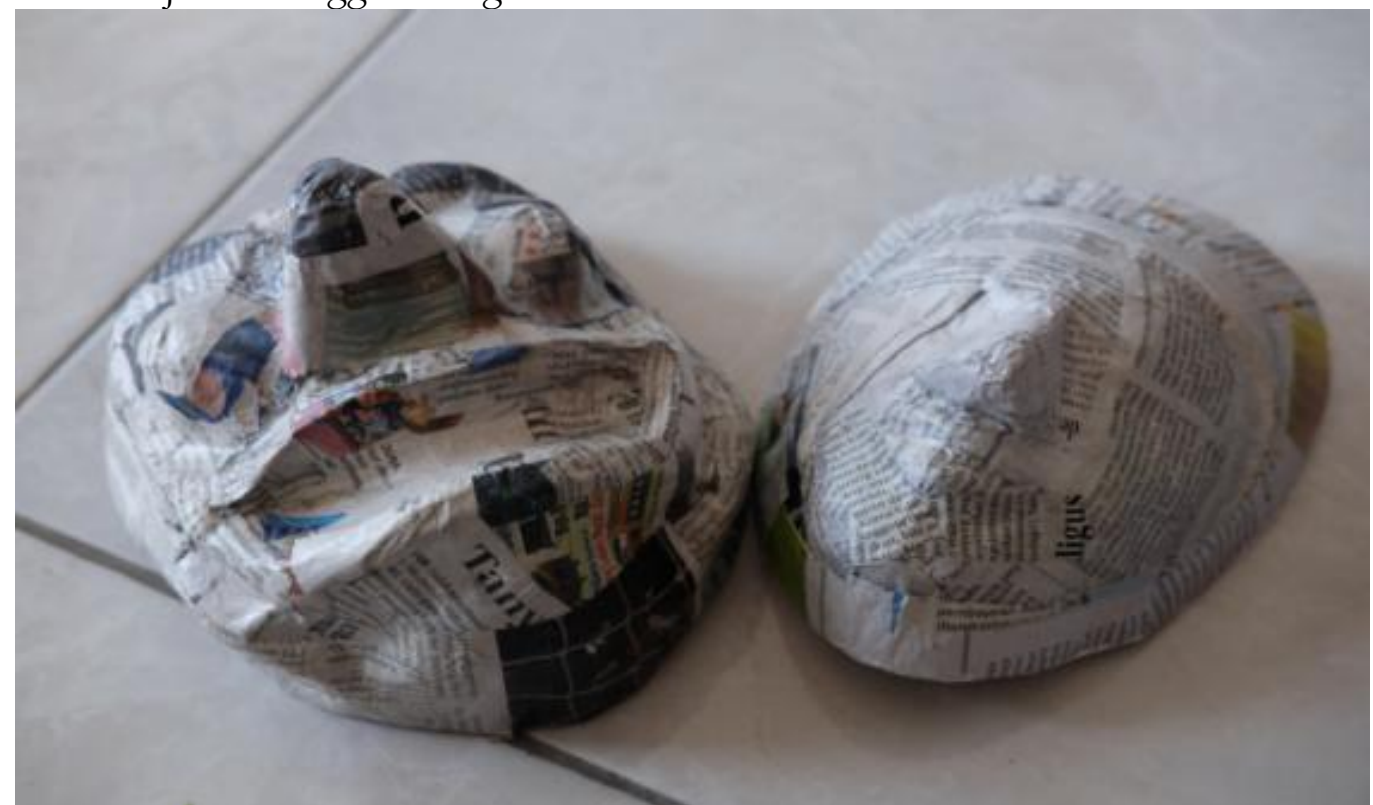

Gambar 4. Topeng Wayang Kerte yang telah dicetak dan ditempel dengan kertas ( Foto : Setiawan, 2018)

Bahan tersebut di atas kemudian masuk pada proses pewarnaan. Proses pewarnaan diawali dengan warna putih, lalu kemudian menggambar sesuai dengan karakter tokoh yang diinginkan.

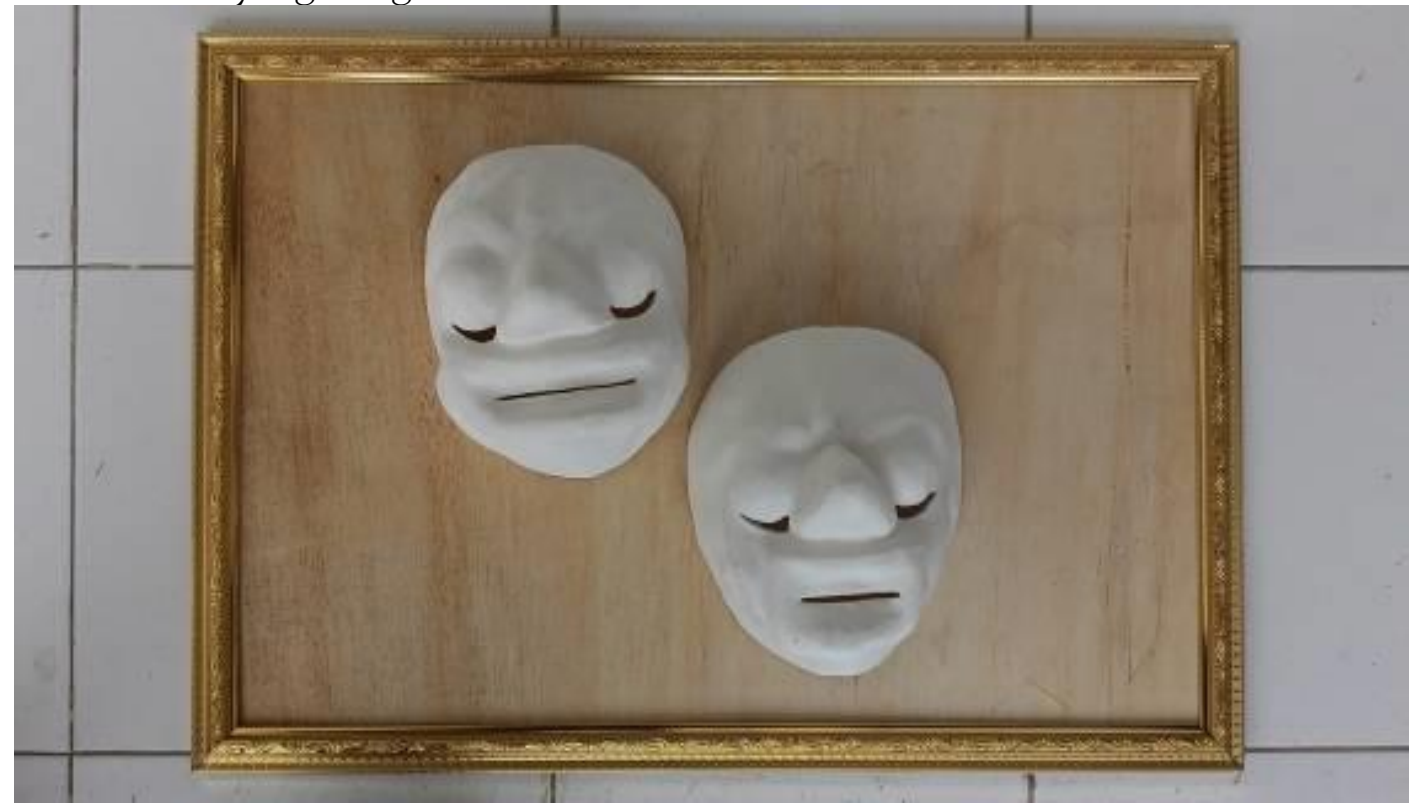

Gambar 5. Topeng yang siap diberi warna sesuai karakter tokoh (Foto : Setiawan, 2018)

Tahan selanjutnya adalah memberikan warna sehingga menjadi topeng kerte yang siap untuk digunakan sebagai properti pertunjukan. Berikut contoh-contoh topeng kerte yang sudah dapat digunakan sebagai property pertunjukan. 


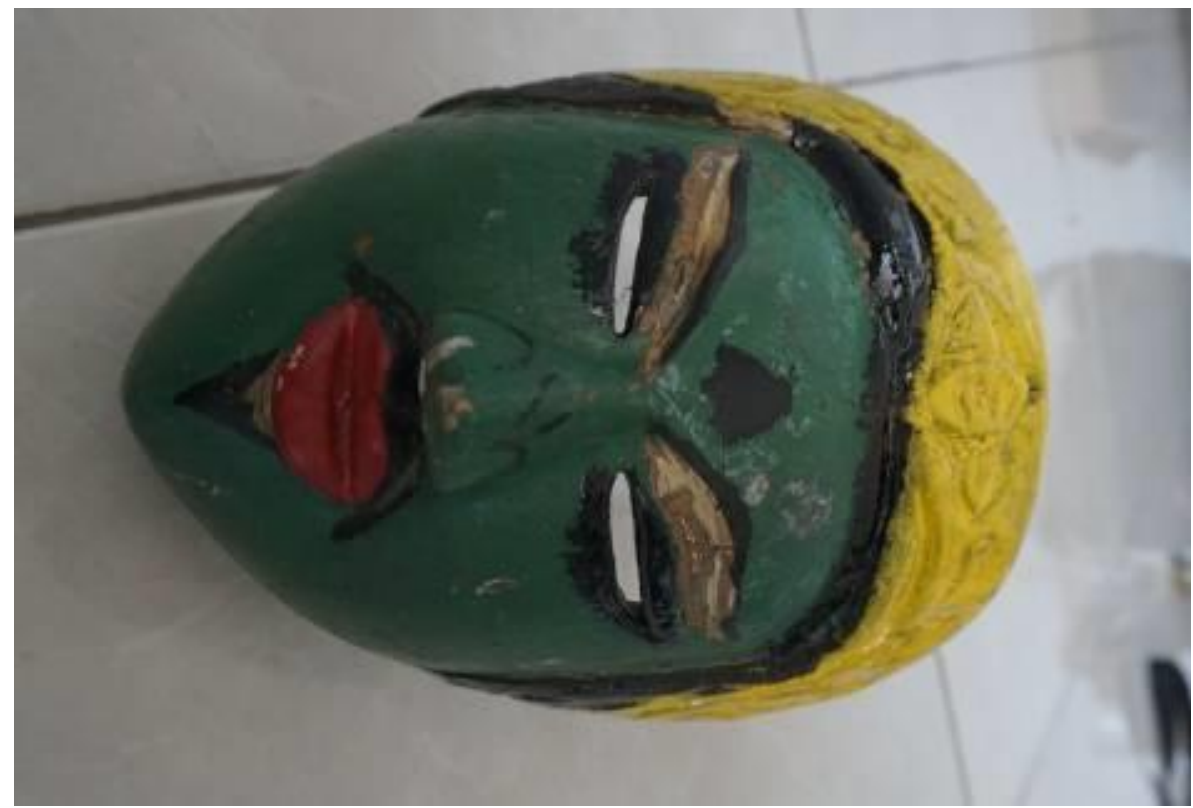

Gambar 6. Topeng Wayang Kerte yang sudah jadi. (Foto: Setiawan, 2018)

D. Pelatihan Pembuatan Variasi Produk Topeng Kerte

Seperti dipaparkan di awal bahwa masyarakat Kotakan belum mampu mengembangkan topeng Kerte menjadi produk dengan varian lain. Mereka memproduksi topeng Kerte untuk keperluan pertunjukan. Dari sana apabila pertunjukan topeng Kerte menurun maka produksi topeng Kerte dipastikan menurun. Maka salah satu cara untuk dapat memproduksi topeng Kerte adalah mencari varian lain agar topeng Kerte tidak hanya sebagai benda properti pertunjukan tetapi hadir dalam dimensi lain.

Untuk alasan maka tim Pengabdian Unej menghadirkan ahli seni rupa untuk nantinya dapat memberikan contoh varian yang dimaksud. Pada pelaksanaan pelatihan ini menghasilkan dua varian produk topeng wayang Kerte. Varian produk pertama adalah tempat lampu dan kedua adalah pigura topeng kerte. Berikut hasil yang dimaksud.

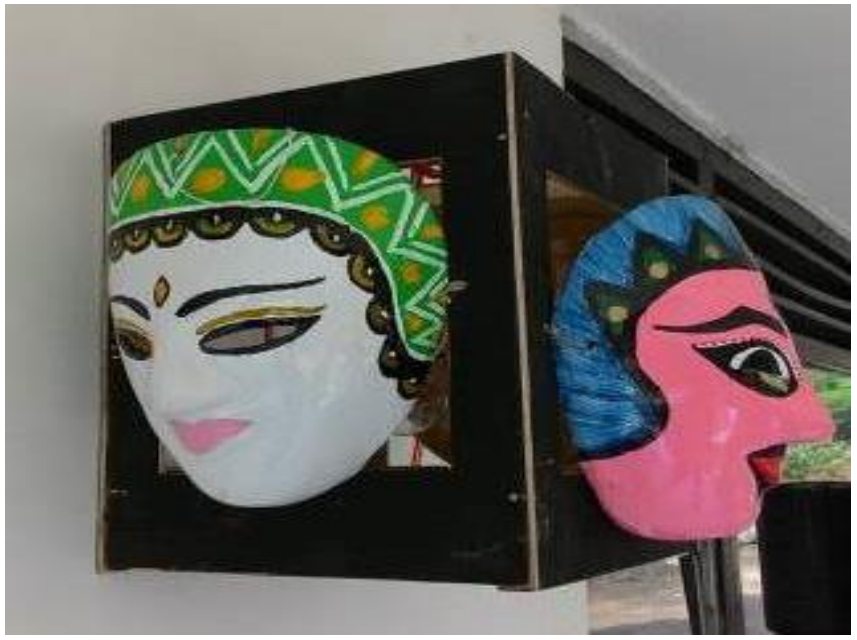

Gambar 7. Varian Produk Topeng Kerte menjadi Tempat Lampu.

(Foto: Setiawan, 2018) 


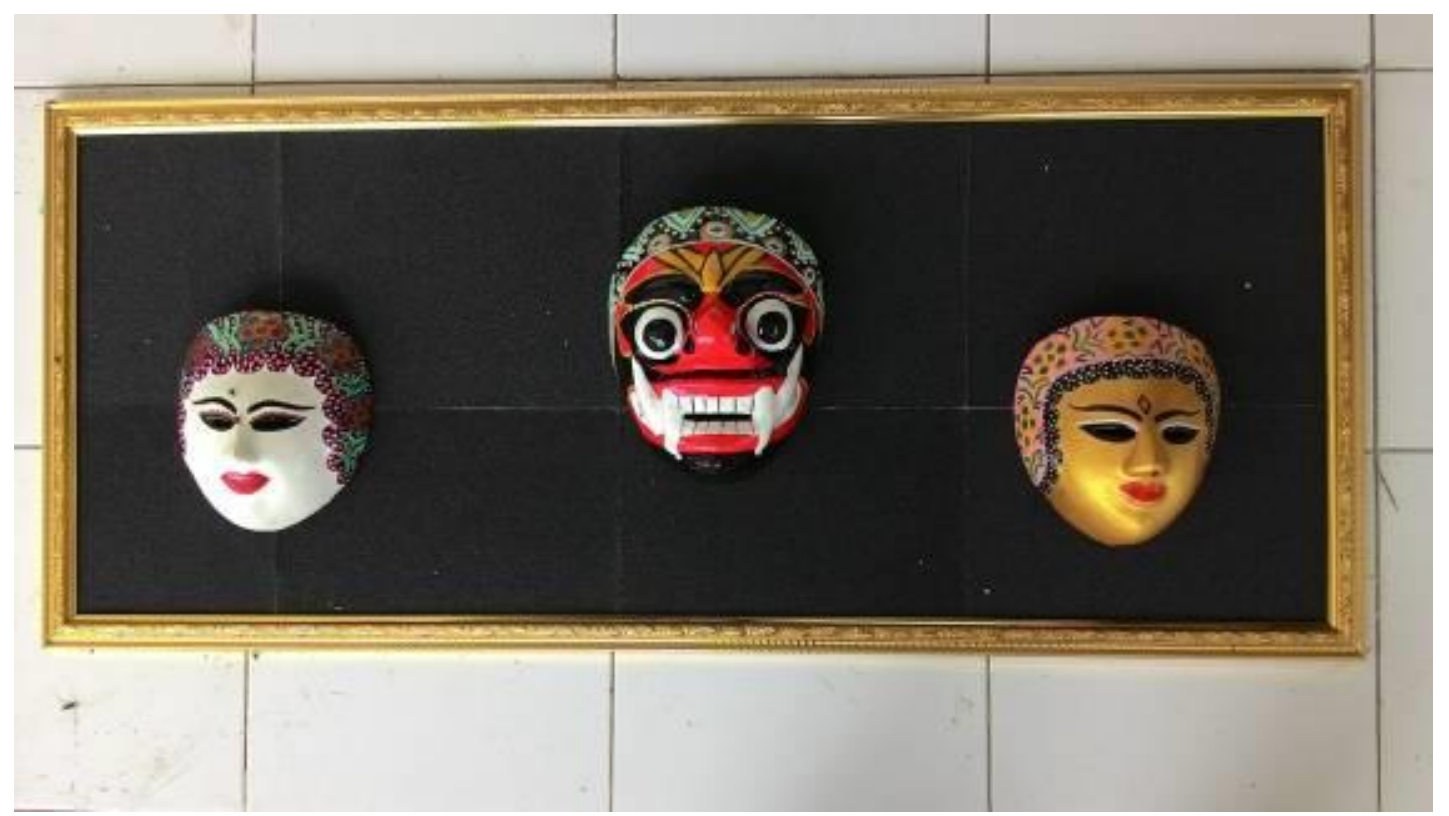

Gambar 8. Varian Produk Topeng Wayang Kerte berupa Pigura Wayang Kerte.

(Foto : Setiawan, 2018)

\section{E. Pembuatan dan Pengelolaan Web}

Manajemen pemasaran yang dimaksud dalam pengabdian ini adalah dengan cara daring. Mengingat bahwa era 4.0 saat ini, akses internet merupakan sesuatu yang tidak dapat dipisahkan dari kehidupan masyarakat. Begitu pula dengan masyarakat Desa Kotakan. Melalui pengabdian ini masyarakat Desa Kotakan melalui komunitas Kaliyuga dibuatkan web/ halaman daring khusus untuk mengupload produk-produk topeng wayang kerte Kotakan berikut pelatihan untuk mengelolanya.

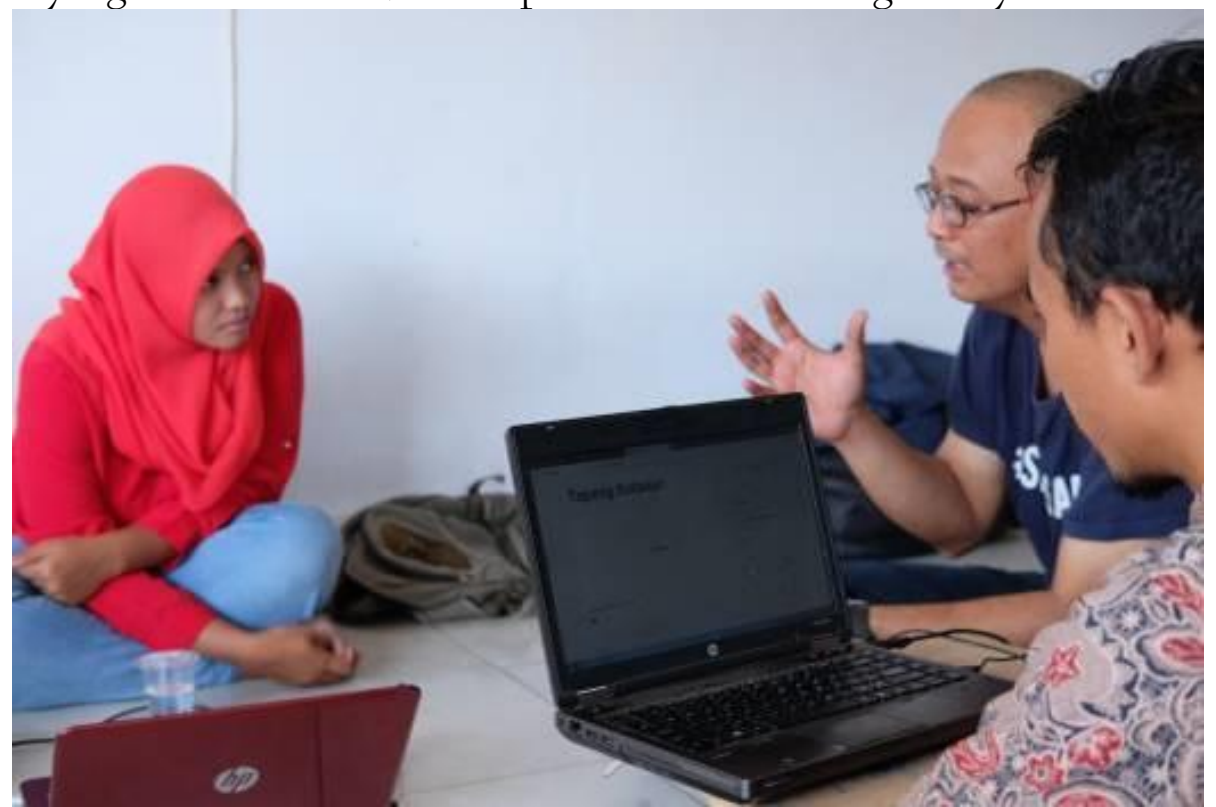

Gambar 9. Pelatihan pengelolaan web di Desa Kotakan. (Foto : Setiawan, 2018)

Hasil dari pelatihan tersebut, kini Desa Kotakan mempunyai web yang khusus untuk membahas informasi mengenai sejarah, proses pembuatan, produk dan juga 
potensi lainnya terkait topeng wayang Kerte Situbondo. Saat ini bila ingin mengetahui tentang topeng Kerte Kotakan dapat mengunjungi alamat www.topengkotakan.com.

\section{Topeng Kotakan}

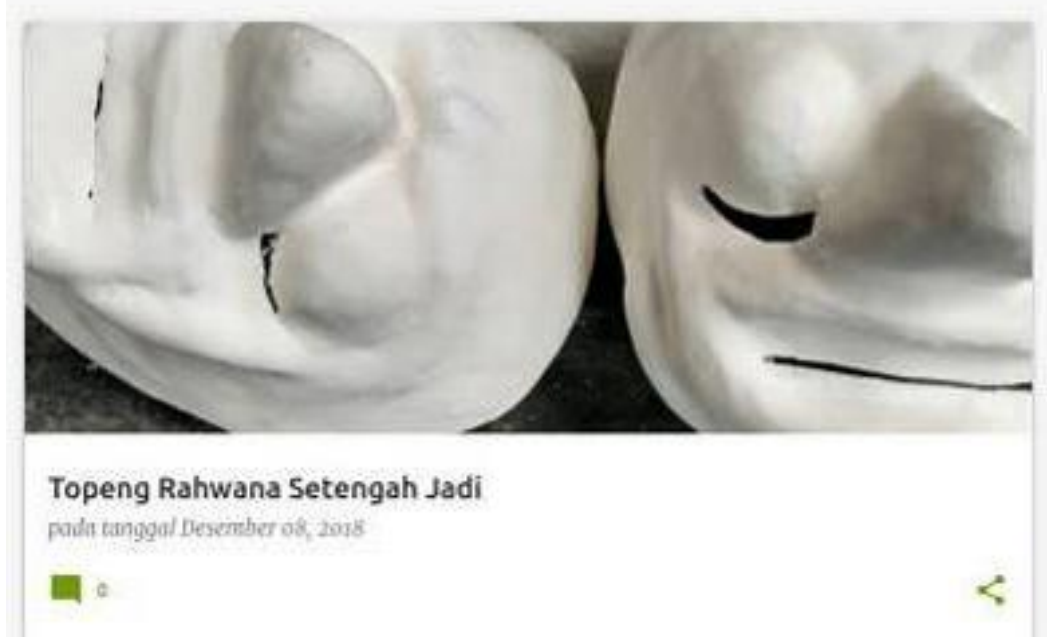

Gambar 10. Tampilan Halaman Web Desa Kotakan (Foto: Setiawan, 2018)

\section{F. Video Company Profile}

Selain menghasilkan produk-produk di atas, dalam pengabdian ini juga membuat video company profile Desa Kotakan. Seperti halnya web, bahwa video ini dikhususkan untuk mengenalkan potensi Desa Kotakan yang notabene merupakan sentra industri topeng wayang Kerte. Dengan pembuatan video tersebut diharapkan nantinya Desa Kotakan lebih dikenal di Kabupaten Situbondo sebagai sentra industry topeng Kerte tetapi juga dikenal oleh masyarakat luas, bahkan masyarakat dunia. Video yang dimaksud dapat dilihat di link berikut https://drive.google.com/open?id=lrf9EtptG3wgRZ6VNtA58670cdf34XKnc).

\section{G. Konsep Galeri}

Hasil observasi kedua adalah membuat rancangan kasar art galery di Desa Kothakan Kabupaten Situbondo. Pada saat observasi dilakukan, Kepala Desa memberikan beberapa tempat yang dimungkinkan untuk digunakan sebagai art galeri. Akhirnya dari beberapa tempat tersebut terdapat satu tempat, di mana tempat tersebut dihibahkan oleh Sekdes setempat untuk digunakan. Sekdes di sini merupakan pemilik tanah sehingga legalitasnya terjamin. Berikut foto-foto lokasi yang dimaksud. 


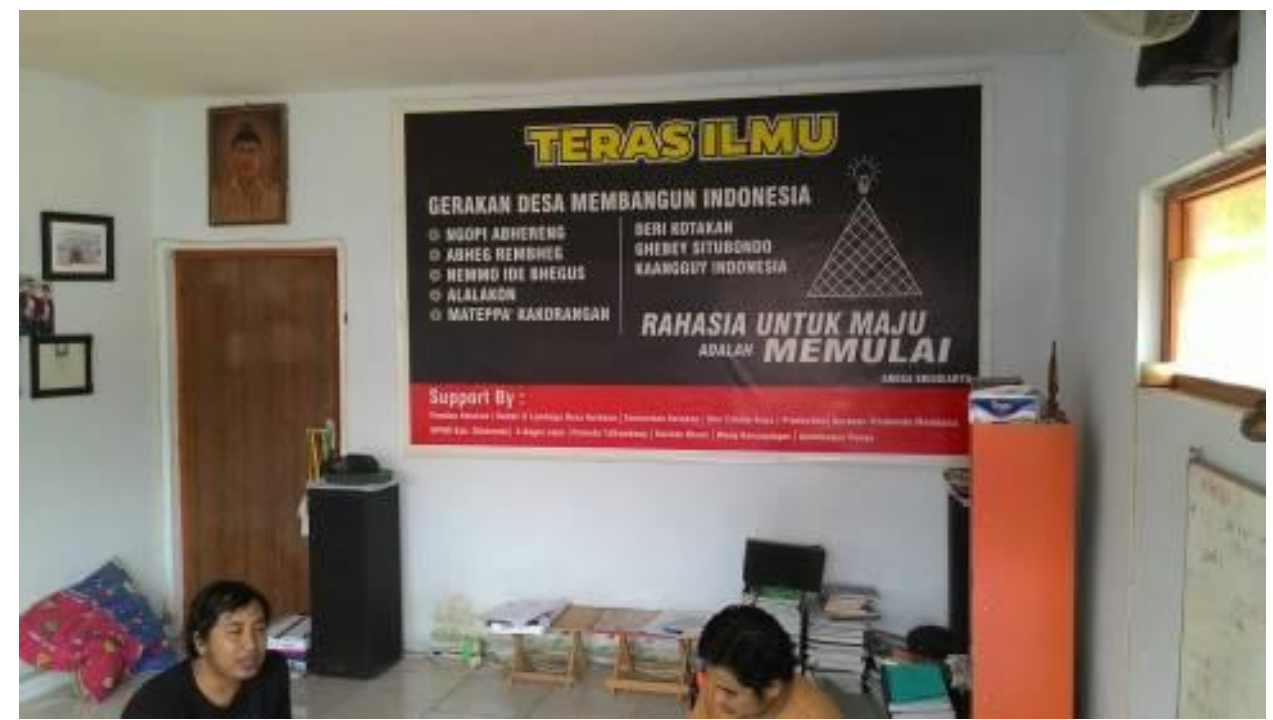

Gambar ll. Calon Ruang untuk art galery l (Foto: Setiawan, 2018)
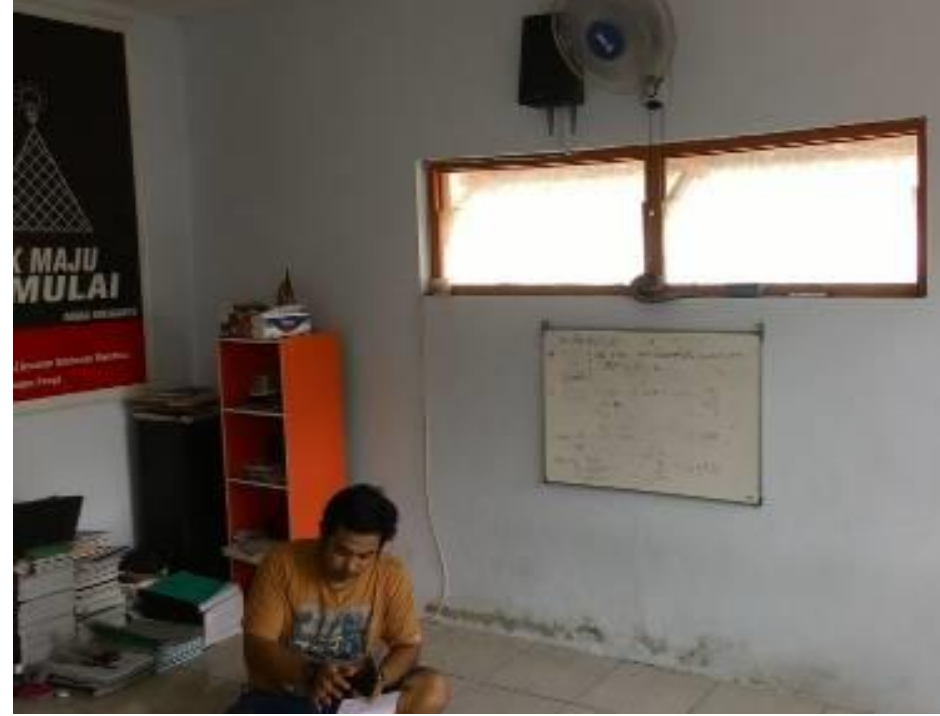

Gambar 12. Ruang art galery 2 (Foto: Setiawan, 2018)

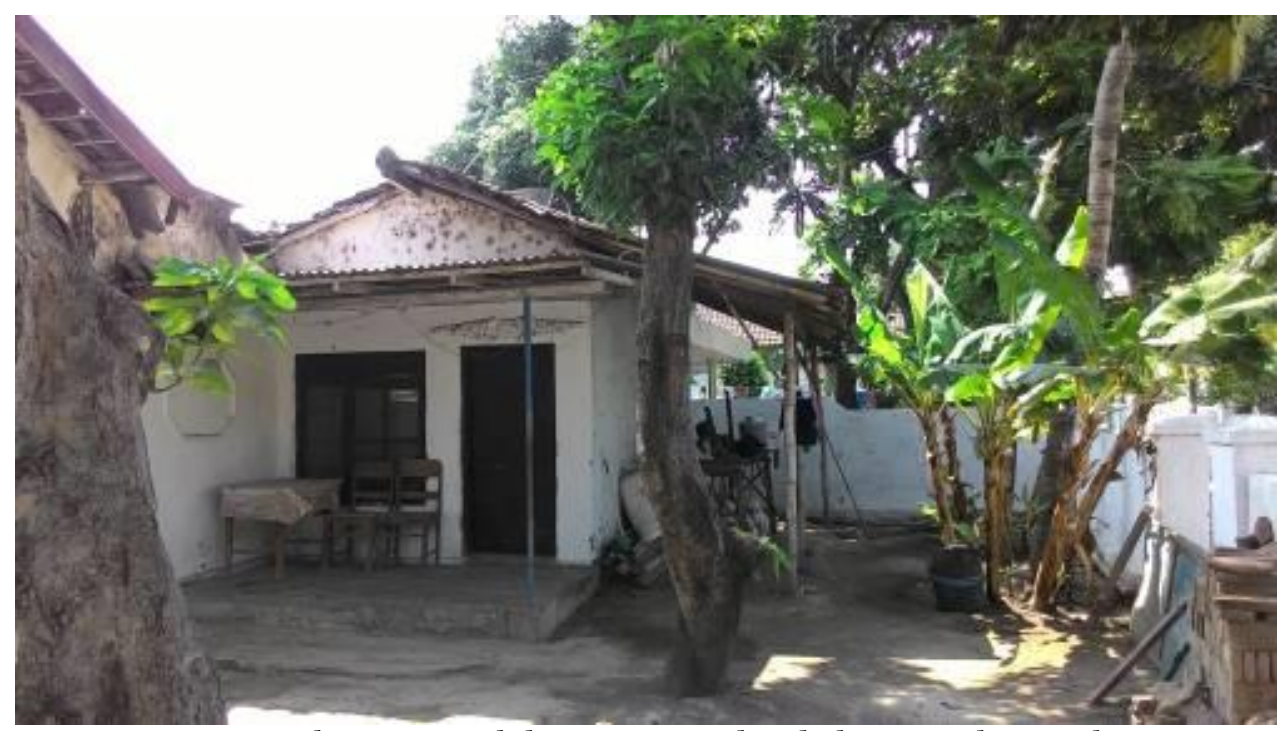

Gambar 13. Tanah kosong yang disediakan untuk art galery 
(Foto: Setiawan, 2018)

Dari hasil-hasil observasi tersebut Kepala Desa meminta konsep art galery untuk digunakan sebagai acuan dalam proses pembuatan galeri untuk topeng Kerte di desa Kothakan. Konsep galeri yang kemudian kami serahkan adalah galeri art semi cafe, di mana dalam ruang tersebut akan terdapat ruang produksi topeng wayang kerta, ruang pameran topeng wayang kerte, dan cafe. Sehingga galeri topeng kerte nantinya tidak hanya sebagai sarana publik seperti tempat kunjungan wisata tetapi juga menjadi area kuliner desa Kotakan.

Berikut adalah konsep kasar galeri yang dimaksud.

$\begin{array}{ll}\text { Keterangan: } \\ \text { 1. } & \text { Galeri Topeng } \\ \text { 2. } & \text { Galeri Sovenir 1 } \\ \text { 3. } & \text { Galeri Sovenir } 2 \\ \text { 4. } & \text { Ruang Produksi } \\ \text { 5. } & \text { Cafe } \\ \text { 6. } & \text { Pintu Utama } \\ \text { 7. } & \text { Gasebo 1 } \\ \text { 8. } & \text { Gasebo } 2 \\ \text { 9. } & \text { Gasebo } 3 \\ \text { 10. } & \text { Gasebo } 4 \\ \text { 11. } & \text { Gasebo } 5 \\ \text { 12. Kamar Mandi } \\ \text { 13. } & \text { Ruang Diskusi }\end{array}$

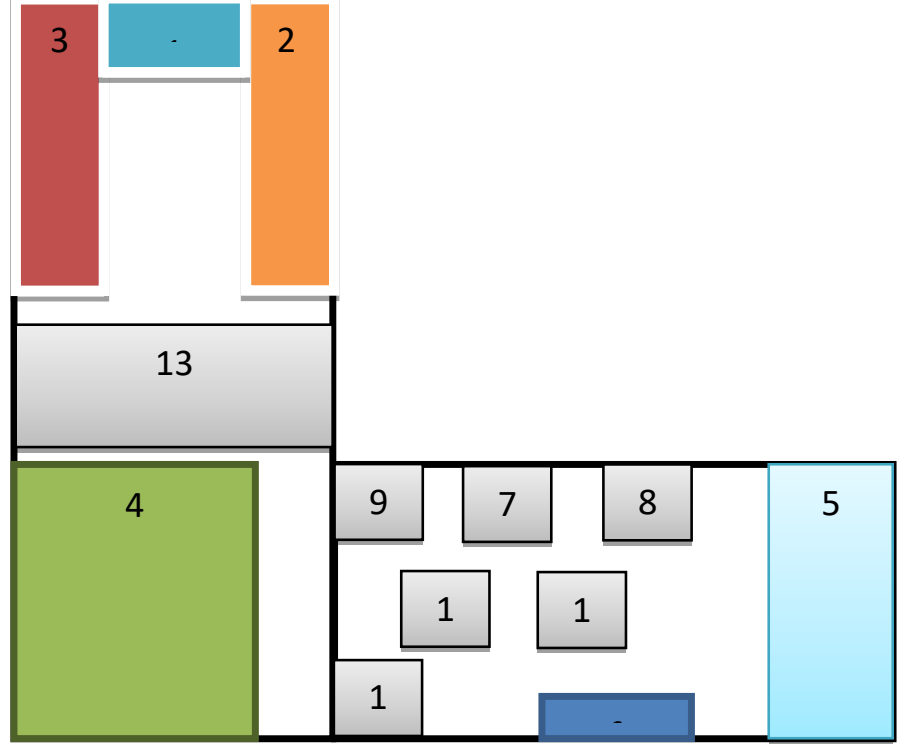

\section{Road Map}

Hasil observasi di atas kemudian berkembang pada diskusi lebih lanjut mengenai kelanjutan kerja sama, sehingga menghasilkan road map sebagai berikut:

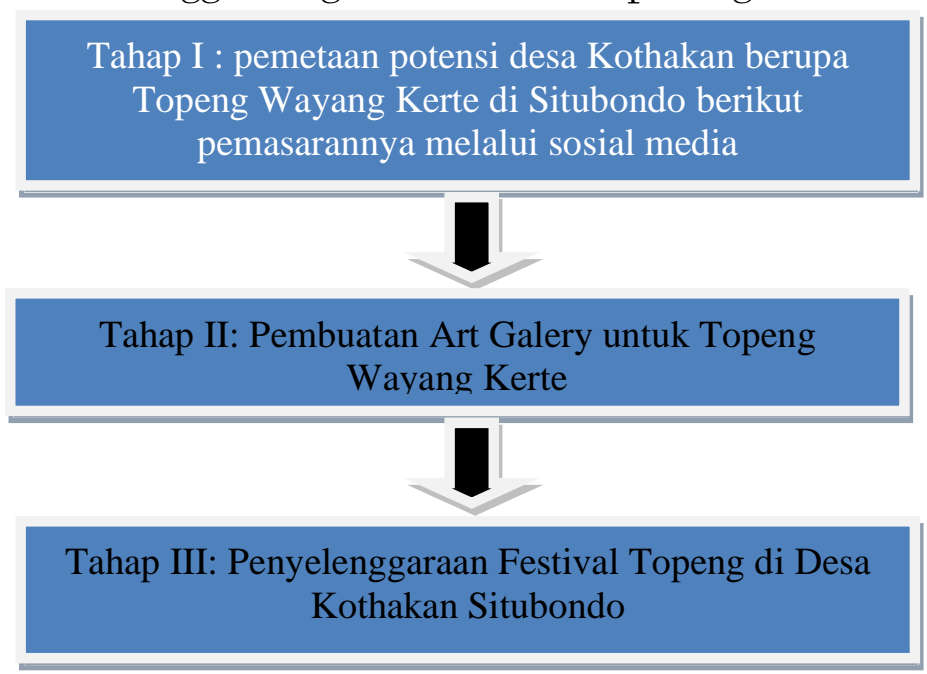


Pengabdian terhadap kelestarian Topeng Wayang Kerte di Desa Kotakan Kabupaten Situbondo salah satunya dengan cara mentransfer metode pembuatan pengrajin Topeng Kerte kepada anak-anak muda yang berminat. Bagi yang telah mampu membuat Topeng Kerte diberikan pelatihan mengenai membuat varian Topeng Kerte. Varian produk membantu para pengrajin untuk berinovasi agar mereka tidak hanya memproduksi topeng wayang sebagai aksesoris pertunjukan tetapi juga dapat digunakan sebagai produk seni lain. Dalam hal ini tim pengabdian Unej member pelatihan bagaimana membuat Topeng Wayang Kerte menjadi hiasan dinding dengan cara dipigura, dan juga membuat Topeng Kerte menjadi lampu hias. Sedangkan untuk memasarkan produk-produk mereka, pengabdian ini juga memberikan pelatihan mengenai pembuatan web dan cara pengelolaannya. Dari sana diharapan Desa Kotakan mampu memasarkan produk Topeng Wayang Kerte melalui media daring. Hal ini berbanding lurus dengan program Pemerintah Kabupaten Situbondo yang mencanangkan dirinya pada tahun 2019 sebagai Tahun Kunjungan Wisata serta respon terhadap era 4.0 yang telah ditetapkan pemerintah. Kedepan Desa Kotakan tetap membutuhkan pendampingan guna mencapai road map yang telah disusun oleh tim pengabdian bersama pemerintah desa serta komunitas pelestari Topeng Kerte, Komunitas Kaliyuga. Hal yang akan dilakukan di masa depan paling tidak ada dua hal. Pertama terkait penyusunan Galery Art - yang dalam pengabdian ini tim pengabdian hanya menyumbangkan ide dasarnya - dan mengadakan Festival Topeng Kerte di Desa Kotakan Situbondo. Dua hal terakhir inilah yang kedepan membutuhkan pendampingan.

\section{VI.DAFTAR PUSTAKA}

Bovier, Helena. 2002. Lebur: Seni Musik dan Pertunjukan dalam Masyarakat Madura. Forum Jakarta-Paris, Yayasan Tradisi Lisan dan Yayasan Obor Indonesia, Jakarta.

Hidayah, Ma'ruf Ihwan, Tjintari. "Karakteristik Visual Topeng Kerte Kesenian Tradisional di Desa Kotakan Kecamatan Situbondo Kabupaten Situbondo". Jurnal Pendidikan Seni Rupa, Vol 3 No 1 Tahun 2015, 103-112.

Hidayatullah, Panakajaya.2018. "Topeng Retak di Wajah Wayang Kerte”. Majalah Cak Durasim: Taman Budaya Jawa Timur, 41-42.

\section{Webtografi}

www.situbondokab.go.id 